\title{
Effect of Total Quality Management (TQM) on the Non-Financial Performance of Hospitals in Ekiti State
}

\author{
Abiodun Rafiat Ayeni-Agbaje (Ph.d) ${ }^{1} \quad$ Raphael Adekola Dada ${ }^{2} \quad$ Isaac Adesodun Adebayo (Ph.d) ${ }^{1}$ \\ Oluwasegun David Ojo ${ }^{3}$ \\ 1.Department of Accounting, Faculty of Management Sciences, Ekiti State University, Ado-Ekiti, Nigeria \\ 2.School of Business, University of Aberdeen, UK \\ 3.Department of Business Education, Ekiti State University, Ado-Ekiti, Nigeria
}

\begin{abstract}
This study examined the effect of TQM on the non-financial performance of hospitals in Ekiti State, Nigeria. The study adopted a descriptive survey design and the population for this study covered all the 4371 staffs of public Tertiary Institutions in Ekiti State. Using Taro Yamane formula (1967), the sample size for this study was 367 workers. A self-structured questionnaire was used to elicit the needed information from the sampled respondents. The data were analyzed using multiple linear regression. It was discovered that customers focus, employee involvement and supplier partnership exert a positive but insignificant effect on the treatment outcome of hospitals in Ekiti State. Also, the result revealed that management commitment and training have a positive and significant effect on the treatment outcome of hospitals in Ekiti State. Also, the study revealed that customer focus, management commitment, employee involvement, supplier partnership and training exert a positive and significant effect on the increased patronage of hospitals in Ekiti State, Nigeria. Thus, the results suggest that the management should initiate total quality management initiatives that network the entire organization regularly to attain and sustain high-quality standards and meet customer needs and expectation.
\end{abstract}

Keywords:Total Quality Management, Total Quality Management Practices, Non-Financial Performance treatment outcome, Increased Patronage, Customers Focus, Employee Involvement, Supplier Partnership

DOI: $10.7176 /$ RJFA/12-10-02

Publication date:May $31^{\text {st }} 2021$

\subsection{Introduction}

In recent times, service organizations like healthcare organizations, banks, hotels and educational institutions in Nigeria seem to be confronted with quality challenges occasioned by technology, globalization, constant shift in customers' needs or satisfactions and intense competition from local and foreign organizations. Customers across the globe are becoming more aware of the rising standard of living given their access to a wide range of services to choose from with a view to enjoying maximum satisfaction from their limited resources. To stay relevant in the industry and win more customers without betraying the loyalty of existing ones, Ali and Alolayyan (2013) and Mohamed (2015) note that delivering quality service is considered an indispensable approach for success, survival and for breeding higher performance.

Higher performance is the central objective of every organization whose aim is to maintain going concern in the industry. World Health Organization (2011), Pambrenia, et al, (2019) considered quality performance as one of the efficient approaches for business organizations to improve their competitive advantage and achieved the organizational goals. Performance is described as the process of quantifying the effectiveness and efficiency of operational activity (Mohammed, 2015, Cai, 2009). While effectiveness revolves around the extent to which the requirements of customers are met, efficiency reveals how organizations economically manage her limited resources in providing customer satisfaction. Brian et al. (2016); Li and Collier (2000); Ali and Alolayyan, (2013) noted that the health sector operational performance revolves around treatment outcome, on-time service delivery, increased patronage, and operational efficiency.

Therefore, the well-being of a society is a central factor in the long-term socio-economic development of any nation. A health care system comprises of small and large entities, such as health centers, pharmacies, medical clinics, National Health Insurance Services Agencies (NHIS) and teaching/specialist hospitals (Brian et al., 2016; Ali \& Alolayyan, 2013). It is recognized that the improvement of health as a social development institution has a humane value in itself, independence of other economic or political considerations as stated by World Health Organisation (WHO), (2011). At the same time, there is a relationship between improved health and economic productivity since health contributes to the formation and preservation of human capital. Health is required to be maintaining in other to improve the productivity of the workforce and to make it possible for the pre-work population to take efficient advantage of the investment in educational facilities required for their later performance in life (Ali \& Alolayyan, 2013; El-Moneim \& Atef, 2015).

In Ekiti State, Nigeria, all hospitals provide the same types of services, but it appears not to be of the same quality. Observably, this seems to be connected to an increasing population in the State and rising health care cost somewhat occasioned by conventional management approaches. Personal observations showed that customers 
seem not to be satisfied with treatment outcomes, delayed service delivery, and operational efficiency. There is underpinning low patronage of customers in some organizations, for example, public hospitals, in some states as noted by (Omogbiya and Addah, 2016). People that need urgent medical attention or seeking medical attention in hospital are always increasing. However, health workers seem not to be concerned about the urgency of medical attention of some patients whose health status is worse or critical. While some claim that regardless of the urgency of the situation, they have to be professional and maintain their calmness; it appears that some are using this as an excuse to be lazy and cold-hearted toward their patient without thorough supervision from the head of department. The unprofessional attitudes such as this could result in poor treatment outcome in the short-run and in the long run, therefore affects the standard of the hospital, quality control, customers' patronage, and overall service quality.

However, as part of management efforts to solve this problem is the adoption of TQM as integrated management philosophy aimed at improving the performance of process of products, and services to achieve high quality and standard that meet or probably exceeds customer expectations/satisfactions as advised by an experts (Ali \& Alolayyan, 2013). On the same vein, the application and practice of TQM in any organization give it the opportunity of adapting the dynamic and changing business environment and flexible operation of member staff in problem solving, customer staff relationship and adequate utilization of opportunities that influence the overall organisational performance. These achievements can only become realizable and feasible through a combined efforts of all work forces (both at management cadre and otherwise) and stakeholders, seeking for management support and leadership, employee involvement, empowerment, education and training, continuous improvement, customer focus and process management especially in the context of hospital (Ali \& Alolayyan, 2013; Alolayyan, 2012; Sadikoglu and Zehir, 2010; Smith and Offodile, 2008).

The aim of this research work is to develop and propose a conceptual synergy that reflects the relationship between the implementation of principle and practices of total quality management and their impact on the quality performance of the health care industries in Nigeria. We aim to analyze the effect of TQM on the non-financial performance of hospital and if the implementation of TQM can bring about an improvement in the institutions' quality performance, namely in manufacturing and service sectors. Our final conceptual model was statistically validated on a questionnaire sent to the healthcare staff in Ekiti State institutions.

\subsection{Literature Review}

\subsection{Conceptual Issues}

\subsubsection{Total Quality Management}

A customer is a dynamic being whose needs and expectations change intermittently. Therefore, services provided which meet the needs and expectation of customers, could be regarded as quality services. According to Koenia, Erni, Hilmiana, and Waode (2016), quality is the degree to which several characteristics of the products or services meet customer needs and expectations whether stated or not stated. Supporting this, Heizer and Render (2014) defines quality as a total picture of the characteristics of the products/services that can meet customer satisfaction or satisfy customer needs. This informs that quality that revolves getting the best out of the limited resources and satisfying the needs and expectations of customers and stays relevant in the industry.

Total quality management (TQM) is a management approach of an organization that centered on quality, based on the full participation of all its members staff, aiming at long term success through customer satisfaction and benefits to all members of the organization and society (Ali \& Alolayyan, 2013; Omogbiya \& Addah, 2016). Supporting this, Moballeghi and Moghaddam (2011) define TQM as a philosophy and a set of guiding principles that characterize the foundation of an excellent organization. This shows TQM is a systematic approach to quality management, which involve a complete commitment to quality in all spheres of the organization. TQM integrates fundamental management techniques, resources and its implementation and consists of organization-wide efforts to install and make permanent a climate in which an organization continuously improves its ability to deliver highquality products and services to customers (Enu, 2010). It is the popular approach to improving quality and involves the organization's long term commitment to the continuous improvement of quality, throughout the organization and with the active participation of all members at all levels to meet and exceed customer's expectations (Shankar, 2012).

Ciama (2012) also viewed TQM as the situation in which all the activities of all the organisation functions are designed and carried out in such a way that all the requirements of customers are met while reducing internal time and cost, thus enhancing the workplace climate. On the other hand, Ndiokho (2012) notes that TQM involves making a constant effort to identify what the needs of the customers are from time to time and determining how to cater for them. This is based on the recognition of the tendency of time to time changes in customers' needs, desires, and wants to change which may occur in key aspects of the environment such as social, political, economic and technological changes.

Total quality management (TQM) is a systematic quality improvement approach for firm-wide management to improve performance in terms of quality, productivity, customer satisfaction, and profitability (Davood, Hossein, Mohammad \& Arshad, 2013). Since TQM practices have been embraced by many firms around the world for 
decades, they have earned the attention of many researchers from diverse areas. TQM is a management philosophy that is intended to empower every members of the organization. On this basis, Davood, Hossein Mohammad and Arshad (2013) noted that TQM is intended to promote continuous, sustained, and long-term improvement in quality and productivity and to eliminate employees' fear of change. This presupposes that TQM approach integrates the fundamental techniques and principles of quality functions deployment, statistical control, and existing management tools in a structured manner.

\subsubsection{Total Quality Management Practices}

During the last two decades, several studies have shown that TQM has benefited organizations by improving the quality of products and services, helping to present superior quality products to their customers: and enhancing a firm's performance. There are many practices of TQM. Mohamed (2015) affirmed that some practices are peculiar to certain industries. As gathered from the literature, customer focus, employees' involvement, management support, suppliers' partnership and training of staff are TQM practices relevant to the health sector (Moneim \& Atef, 2015; Diamond, 2015).

Top management is a veritable key to a successful total quality management program as they possess the most influence upon those working in the company. Although they do not produce anything, they get results through other employees and they are responsible for setting the organizational goals and strategies to be followed in achieving them. Their management style comes into play as they try to get the best from their staff whether through an authoritarian or participation approach (Wilson, 2017). According to Pheny and Teo (2003) top management should communicate total quality management to the entire organization to create awareness, interest, desire and action, provide quality vision and create a cultural change within the organization, organize trainings, empower others by allowing them to grow, delegate authority and recognize them for quality achievements. It is also the responsibility of top management to allocate resources and partner with suppliers for the sharing of information on innovations and technology in the market for quality materials.

Top management commitment is required for effective change in organizational culture, which can only be made possible with the deep involvement of top management to the organization's strategy of continuous improvement, open communication and cooperation throughout the organization (Omogbiya \& Addah, 2016). Total quality management implementation improves organizational performance by influencing other total quality management dimensions. According to Diamond (2015), top management is traced to most challenges associated with quality problems. This indicates that successful total quality management is highly dependent on a high level of top management commitment and it requires that top management commitment to quality must express the philosophy that quality will receive a higher priority over cost and that in the long run it will achieve operational performance as well as reduced operational cost.

It is expedient for an organization to focus on customer satisfaction for the success of the organization. Customer satisfaction is the degree to which the customers of an organization continually perceive that their needs are being met by the organization's products and services. This shows that a strong link exists between the delivery of high-quality goods and services and organization success by focusing on the customer through their satisfaction. According to Nganga (2010), customers see quality as the capability to satisfy their needs. Attesting to this, Brian, Chuka, Charles, and Uzodinma (2016) considers quality as the degree to which a specific product satisfies the needs of a specific consumer. It then follows that it is vital that every employee in the organization is involved and committed to establishing and sustaining a high level of customer satisfaction. This is because improving product and service quality creatively reduces costs and raises an organization's productivity which in turn enables the organization to survive fierce competitions in the market and pleases its customers.

Employees do not decide on how they are to be managed, but not all employees can pick up and accept the implementation of changes to management styles made by the organization because management needs to make the change. Hence, management must keep employees into consideration at all times when decisions are being made regarding total quality management, which ought to encourage participation and help ease transition (Enu, 2010). Right training should be given to the right people on the system to be use in an organization which ensures the emphasis on the benefits of using such a system and how they are being used. Training given to the right people has been proven to minimize the misuse of tools and techniques. Continuous and consistent education and training of all employees support the drive for quality. Employees are supposed to be encouraged to take more responsibility, communicate more effectively, act creatively, and be innovative.

Employee involvement is a very simple process. If a decision is to be made which will affect the employees, it is always better to consult them as they may have some intelligent ideas to offer and this will help in building up the relationship between employee and management and also create conducive environment for better results. Hence, organizations need to find ways to communicate successes that reveal how the organization is performing; and to especially find ways to circularize stories of superior performance (James, 2015). A clear, well-planned and high-impact messages can help employees not to only see the connection between their work and these successes, but also work to understand how they sustain overall organizational performance which is tied directly to engagement levels. Engaged employees often understand clearly the value of ensuring positive customer 
experience and are more likely to display their commitment by delivering high-quality products and services. Customer and employee-driven experiences that emphasize great customer satisfaction and loyalty need to be effectively shared all through the company (Nganga 2010).

Training is an essential factor that boosts employee's effort towards improvement. Employees need to be given quality training which includes educating and training employees at all levels in the organization which are focused at providing them with information about the organization's quality mission, vision and generally their desired direction (Sayyad, 2017). Training broadens the knowledge of employees on quality issues and programmes. According to Jamali, Ebrahim and Abbaszadeh (2010), employee training is one of the most important requirements in a successfully total quality management implementation. Management personnel, supervisors and other employees require skills and knowledge on quality dimensions and management as well as their roles in total management quality implementation because market quality needs are very dynamic.

Biodun (2003) cited in, Jamali et al. (2017) point out that employee training that is focused on quality management determines how effective an organization's quality management initiatives will be. On the other hand, Zakuan, Muniandy, Saman and Adrif (2012), opine that investment in employee training and development is a critical component to a successful total quality management implementation. Onware (2012) identified two elements that must be considered before training employees on quality which are knowledge and understanding of the quality management processes and an understanding of quality management tools. A total quality management training program must furnish employees with an understanding of total quality management program and their role in bringing it to success.

Just like customer focus, suppliers are important to the organization and as a result form a critical aspect of total quality management. Materials are purchased from suppliers and they often form a major source of quality problems. Poor quality supplier products result in extra cost for the purchaser and for the party to succeed and business to grow, a partnership is required (Mohamed, 2015). Companies are expected to treat their suppliers as long-term partners because they are a vital part of the organizations' business operations. Quality management practice enables the establishment of relationships among suppliers, customers, and management which enables the promotion and facilitation of communication to mutually improve the effectiveness and efficiency that create value. Various opportunities are available to an organization to increase value through working with their suppliers and customers, such as optimizing the number of suppliers and customers, establishing two-way communication at appropriate levels in both organizations to facilitate the rapid solution of problems and to avoid costly delays or disputes (Mohamed, 2015).

This means that supplier partnership also entails cooperating with suppliers in validation of the capability of their processes and monitoring the ability of suppliers in delivering conforming products to eliminate redundant verifications. It is also essential to encourage suppliers to implement programs for continual improvement of performance and to participate in other joint improvement initiatives, involving suppliers in the organization's design and development activities to share knowledge effectively and efficiently and to improve the realization and delivery processes for conforming products. Finally, involving partners in the identification of purchasing needs and joint strategy development is essential, including evaluating, recognizing and rewarding efforts and achievements by suppliers and partners.

TQM appears to be well established in the literature however, performance remains a loose concept in the sense that different entities seem to have different performance measures. Therefore, this multifaceted idea determines the most appropriate pointers troublesome. Mbugua (2014) noted that the connection between TQM practices and performance has secured generally the hard (financial) performance measures. For example, bookkeeping factors, income, net profit, gainfulness, piece of the overall industry development and less studies has taken a gander at the delicate (non-financial related) performance measures that are connected and which are seldom considered to be immaterial.

This point was noted by Mbugua (2014) who proposes both hard (financial) and delicate (non-financial) measures are required inside the TQM structure. Be that as it may, considering that TQM has a broad concentrate on immaterial and scholarly factors, the investigation went for setting up the connection amongst TQM and nonfinancial related measures have gotten unmistakable quality since the advancement of the 'adjusted scorecard. Performance is the results documenting the connection between what organizations do in terms of quality management practices and the results they achieve in several types of outcomes that are limited to treatment outcome, on-time service delivery, operational efficiency and increased patronage level (Mbugu, 2015).

Non-financial performance measures, for instance, are required to guarantee that procedures are in control and can be persistently made strides. Ittner and Larcker (2005) recommend that TQM practices are identified with Information Systems putting more prominent accentuation on non-budgetary performance measures. Nonfinancial performance measures have a few imperative advantages contrasted with monetary measures given that they are simpler to control than the monetary measures since they are once in a while subjected to open confirmation.

Non-financial performance seeks to improve the effectiveness, competitiveness, and flexibility of 
organizations for the benefit of all stakeholders. The organization's way of planning, organizing each activity which is made up of a number of practices like customer focus, top management commitment, employee training, employees' involvement, process management, supplier teaming, benchmarking, continuous improvement, quality measurement, quality audit, quality planning and leadership are the resultant of operational performance. To facilitate service quality and non-financial performance, Mohamed (2015) submit that hospitals must implement effective human resource strategies involving selective hiring, and retention of physicians and nurses, monitoring of doctors and staff and ensuring that they must continue to meet certain performance and practice standards to retain credentials.

\subsubsection{Non-Financial Measures}

\subsubsection{Increased Patronage}

The application of total quality management helps in streaming processes and ensures a proactive work system ready to counter deviations from the ideal state. The major thrust of total quality management is to achieve productivity and process efficiency by identifying and eliminating problems in work processes and systems. It addresses key problem areas such as mistakes in the work process, redundant processes, unnecessary tasks, and duplicate efforts. Improving process efficiency brings about many benefits in terms of cost, time, customers satisfaction and increased patronage from customers. Once customers are satisfied, they will be willing to patronize the company more.

The major benefits of total quality management in terms of cost savings include the elimination of nonconfirmation and repetitive work, elimination of waste cost, elimination of repairs and rework, reduced warranty and customer support costs, process efficiency leading to improved profit per product or service and fiscal discipline through elimination of unnecessary steps and wasteful expenditure (Martin \& Ruiz-Olalla, 2011). Total quality management also frees up management time from redressing problems and direct management time and efforts to increased production, an extension of range of products and improvement of existing products (Norah, Sbah \& Azrilah, 2015). All these lead to the creation and delivery of quality services that bring about customer satisfaction and increased patronage.

\subsubsection{Treatment Outcome}

There is a long history of using outcomes to assess care quality. The use of outcome data to evaluate health care dated back to more than 150 years (Sepucha \& Mulley, 2009). Simon, et al. (2006) noted that to use medical outcomes as a quality measure, one must usually calculate rates of certain outcomes for a group of patients since outcomes are determined by many factors and thus one usually assesses whether the probability of death, for example is higher or lower for one group compared to another. One could also develop explicit a priori criteria to determine whether the observed results of care are consistent with the outcome predicted by a model that has been validated based on scientific evidence (Brook, McGlynn \& Cleary, 2016). Outcome measures reflect the impact of the health care service or intervention on the health status of patients.

Outcomes now have been incorporated into a broad range of health care activities. Physicians providing clinical care routinely ask patients about outcomes to guide their therapy. In clinical research, patients' outcomes provide a measure of effectiveness of different medical interventions. Outcome measures also have been used in health care organizations and systems to assess the quality and guide efforts to improve it. Over the past decades, there have been an increasing number of efforts to release information on patients' outcomes publicly. Most of the efforts to monitor and/or report outcomes systematically have focused on mortality or other outcomes such as inhospital complications, and physiologic function. However, such measures do not adequately reflect the full range of variations in health care activities affected by the quality of care a patent enjoy which are crucial or important to individuals. It is also important to measure the impact of medical and surgical care on symptoms, functioning, and emotional well-being. These types of outcomes often are referred to collectively as health-related quality of life (Wilson \& Cleary, 2015).

\subsection{Theoretical Paradigm Joseph Juran's Theory}

Joseph Juran propounded his popular "Quality Trilogy." in 1989, which has the basic documentations of quality planning, quality control, and quality improvement. If a quality improvement project is to be successful, then all quality improvement actions must be carefully planned out and controlled. Juran gave explanation on the management dimensions of planning, organizing and controlling and focused on the responsibility of management to achieve quality and the need for setting goals. Juran defines quality as fitness for use in terms of design, compliance, availability, safety, and field use. Thus, his concept incorporates the viewpoints of the customer. The theory measures every aspect of the system and focuses on problem-solving techniques, unlike Deming who focuses on top-down management and technical methods rather than worker's pride and satisfaction.

Juran gave a ten-step approach to quality improvement which are building of awareness, opportunity to improve, setting of goals for improvement, organizing to reach goals, provision of training, execution of projects to solve problems, reporting of progress, giving recognition, communication of results, keeping score and 
maintaining momentum by making annual improvement part of the regular systems and processes of the company. This theory conceptualizes on how to proffer better service outcomes to patients in relations to TQM principles. This implies that it will enable top management of hospitals in Ekiti State to focus on their responsibility of achieving quality and the needs of setting goals.

\subsection{Empirical Review}

Many studies have been conducted on TQM and its interface non-financial performance of firms. Mustafa, Nizamettin, Selim and Mehves (2005) examined critical factors of total quality management and its effect on performance in the health care industry in Turkey. The study examined Non-financial measures and supplement financial measures in providing support for total quality management. Secondary data was use and data were analyzed using Cronbach's alpha, Pearson correlation, and canonical correlation. It was discovered that the implementation of total quality management in the healthcare industry in Turkey is found to have a strong positive correlation with business performance. Financial and non-financial performance measures were used in the study such as productivity of labor and profits, consumer behavior- customer satisfaction and loyalty.

Enu (2010) made use of non-financial performance measures such as motivation and performance to examine the impact of total quality management on motivation and performance of Nigerian customs service. The work was analyzed using the chi-square test. The study revealed that the challenges of development are possible through practical and effective implementation of total quality management. In summary, the performance of an organization is one of the clearest indicators of the validity of its strategies and a vital predictor of whether it will be relevant or remain business. The study was focused on Custom Service.

Martin and Ruiz-Olalla (2011) made used of non-financial performance disaggregated into innovation satisfied, defective goods, delivery skills, and resource variance to examine the contributions of non-financial measures in quality environments to business performance in Spain. The study made used of questionnaire and analyzed the data using regression analysis. The findings showed that companies implementing TQM practices above the mean level are also those that organize non-financial measures to a greater degree. Furthermore, the results confirmed such measures' positive impact on business performance, thus corroborating this effect as independent from the level of TQM implementation

Nwadukwe and Court (2013) made an empirical investigation on the effect of total quality management on industrial performance in Nigeria using the ordinary least square method. It was discovered that quality control is one of the indispensable elements of total quality management which improves the performance of the brewery industry in Nigeria. The study found that the cost of quality control had a non-significant positive effect on industrial performance while expenditure of salary on labour had a non-significant negative effect on industrial performance. The study focused on the industrial sector of Nigeria.

Esin and Hilal (2014) examined the effects of total quality management practices on performance and the reasons for and barriers to total quality management practices in Turkey. Regression was used to analyze the data elicited from the sampled respondents using questionnaires. The study used both financial and nonfinancial performance measures such as inventory management performance, employee performance, innovation performance, customer results, market, and financial performance. This study has shown that different TQM practices significantly affect different performance outcomes.

Abdul-Azeez and Olateju (2015) also examined the effects of total quality management practices on customer satisfaction in Nigerian airlines using financial and non-financial performance measures such as top management commitment, reward and recognition. Data was collected through secondary and primary data and analyzed using Cronbach's alpha. It was revealed that all the total quality financial management practices adopted in the study have a positive relationship to customer satisfaction though at varying levels. This study focused on Nigerian airlines thereby creating room for further study.

Brian et al. (2016) using non-financial performance measures such as treatment outcomes and promotion of patronage of service, examined the issues and prospects of health care quality management in Nigeria public sector. It was discovered that quality management improves treatment outcomes, promote patronage of our services leading to declining in medical tourism, brain drain, and the huge foreign exchange lost annually. This present study advanced on the study under review by using more non-financial performance variables such as increased patronage, operational efficiency, and on-time delivery.

James (2015) using financial and non-financial performance measures such as product quality, product innovation, and process innovation, aimed to provide comprehensive insights into the impact of total quality management on the performance of Nigerian organizations in the Nigerian banking industry. This study made use of both primary and secondary data and data analysis was done using correlation analysis and multiple regression. The results showed that the relationship between TQM and organizational performance is significant in a crosssectional sense, in that TQM practice intensity explains a significant proportion of variance in the performance of banks in Nigeria. While the study under review focus on the banking sector, this present study focuses on public hospitals in Ekiti State. 
Diamonds (2015) assessed the effects of total quality management practices on the operational performance of the private health sector in Kenya. Primary data was collected through administered questionnaires and secondary data was also used. Data analysis was carried out using Pearson correlation coefficient. It was discovered that total quality management practices have a significant effect on operational efficiency and performance. Thus, it reduced operation costs, which results in increased hospital profitability, enhanced sales, increased hospital competitiveness, and increased market share.

Ameen, George, Belal and Muhammed (2015) using data gathered via secondary and primary sources (financial report and questionnaire) and using Pearson correlation analysis, examined the impact of total quality management on financial performance in Irbid Province of Jordan Islamic bank. It was discovered that there was a statistically significant effect of total quality management on liquidity ratio of the Islamic Bank of Jordan and that there is a statistically significant effect of total quality management on the profitability ratio in the Jordan Islamic Bank.

Norah, Sbah and Azrilah (2015) examined the impact of total quality management on organizational performance in Pakistan using data gathered from secondary sources like academic journals and thesis, after which analysis was done using content analysis. The findings indicated that TQM has two organizational performances, either is TQM practices affect the organizational performance, or it hinders organizations to achieve their goals in which this will negatively affect the organizational performance.

El-Moneim, and Atef (2015) empirically examined the impact of applying total quality management principles on the overall hospital effectiveness in the HCAC accredited governmental hospitals in Jordan. Both primary sources (questionnaire) and secondary sources were used and analyzed with correlation analysis. It was discovered that a significant positive relationship between total quality management principles and hospital effectiveness and the findings of the study also revealed that total quality management principles had a significant positive impact on hospital effectiveness in the HCAC accredited governmental hospital in Jordan which led to an increase in the hospital performance

An analysis of quality management practices and organizational Performance of Private Healthcare Facilities in Nairobi County, Kenya was conducted by Beatrice, Patrick, and Bulitia (2016). Primary and secondary sources of data were used and analyzed using Pearson correlation coefficient. It was discovered that quality management practices (Information, communication technology, process management, top management support) were significant predictors of organizational performance. Financial and non-financial performance measures were used

Rula (2017) made used of customer focus, leadership, continuous improvement, employee's involvement, fact-based management, process management, strategic management and supplier involvement, operation efficiency and employees to examine the impact of total quality management on organizational performance of oil Petroleum Company in Jordan. The study made use of questionnaire and was analyzed using multiple regression, stepwise multiple regression, and Pearson correlation coefficient. The results showed that total quality management has a positive impact on organizational performance.

\subsection{Gap in the Literature}

Total quality management is a philosophy and a set of guiding principles that characterize the foundation of an excellent organization. Based on the researcher's knowledge, there is only one study (Brian et al., 2016) on the quality management of health care services in Nigeria. Interestingly, this study was theoretical without the usage of any specific variables. Although, a quite number of studies have been conducted in other developed and developing nations on the health sectors such as Mustafa, Nizamettin, Selim and Mehves (2005), El-Moneim and Atef (2015), Beatrice, Patrick and Bulitia (2016) and Diamond (2015). Reported findings revealed that TQM practices such as customer focus, employees' involvement, management support, suppliers' partnership and training of staff can improve the non-financial performance of firms in the health sector. However, due to the peculiarities of countries in terms of development level, political climate, cultural and socio-economic status, it might be difficult to generalize these findings in the context of hospitals in Ekiti State where performance measurement seems to be relatively different from what is obtainable in other countries that are highly technologically driven. Based on these backdrops, the researcher is motivated to examine the effect of TQM on the non-financial performance of hospitals in Ekiti State.

\subsection{Methodology}

The study adopted a descriptive research design. The two public tertiary health institution institutions in the state were selected purposively for the study which forms the population of the study. The study covered all the 4371 staff of public hospitals in Ekiti State. Concerning the information gathered from the management of the hospitals, there were 1475 staff in Ekiti State Teaching Hospital, Ado-Ekiti and 2896 staff in Federal teaching Hospital, IdoEkiti. Using the Taro Yamane model of 1964, the sample size for this study was 367, divided into 124 for Ekiti State Teaching Hospital, Ado-Ekiti and 243 staffs in Federal Teaching Hospital, Ido-Ekiti. A self-structured questionnaire was used to elicit the needed information from the respondents and to authenticate the items on the 
questionnaire; the instrument was subjected to validity and reliability tests. After the rationality of the items on the instruments is ascertained through the face and content validity, a pilot study was conducted where 20 questionnaires were administered on respondent in a hospital outside the scope of the study. Thereafter, a reliability test was done through Cronbach Alpha and 0.75 was obtained as the reliability coefficient. The data were analyzed using multiple linear regression. The estimation techniques are R-square, F-statistics, and P-value. The regression models were given thus:

Model One

$\mathrm{TTM}=f($ CUF MCO EIN TRA SPS $)$

Model Two

ICP $=f($ CUF MCO EIN TRA SPS $)$

Where:

CUF $=$ Customer Focus

$\mathrm{MCO}=$ Management involvement

$\mathrm{EIN}=$ Employee involvement

TRA $=$ Training

SPS $=$ Supplier Partnership

TTM $=$ Treatment Outcome

$\mathrm{ICP}=$ Increased Patronage

$f=$ functional relation

The regression equations were given below:

$\mathrm{TTM}=\alpha_{0}+\alpha_{1} \mathrm{CUF}+\alpha_{2} \mathrm{MCO}+\alpha_{3} \mathrm{EIN}+\alpha_{4} \mathrm{TRA}+\alpha_{5} \mathrm{SPS}+\mathrm{U}$

$\mathrm{ICP}=\alpha_{0}+\alpha_{1} \mathrm{CUF}+\alpha_{2} \mathrm{MCO}+\alpha_{3} \mathrm{EIN}+\alpha_{4} \mathrm{TRA}+\alpha_{5} \mathrm{SPS}+\mathrm{U}$

Where:

$\alpha_{0}=$ Intercept

$\alpha_{1}-\alpha_{5}=$ Coefficient of independent variables

$\mathrm{U}=$ Error term

\subsection{Results and Discussion}

4.1 Results

Table 1: Regression Analysis

Dependent Variable: Treatment Outcome

\begin{tabular}{lllll}
\hline Variable & Coefficient & Std Error & t-statistics & Prob. \\
\hline (Constant) & 3.425 & 0.662 & 5.175 & 0 \\
Customer Focus & 0.022 & 0.05 & 0.434 & 0.665 \\
Management Commitment & 0.118 & 0.048 & 2.461 & 0.014 \\
Employee Involvement & 0.013 & 0.055 & 0.228 & 0.819 \\
Supplier partnership & 0.004 & 0.05 & 0.085 & 0.932 \\
Training & 0.311 & 0.07 & 4.429 & 0.000 \\
\hline
\end{tabular}

R-Squared $=0.490$

Adjusted R-Squared $=0.240$

F-statistics $=6.277$

Prob(F-statistics $)=0.000$

Source: Author's Computation 2021

The OLS estimation result presented in table 1 reveals that customer focus, employee involvement, and supplier partnership exert a positive but insignificant effect on the treatment outcome of hospitals in Ekiti State to the tune of $0.022(p=0.665>0.05), 0.013(p=0.819>0.05)$ and $0.004(p=0.932>0.05)$ respectively. In the same vein, the result shows that management commitment and training have a positive and significant effect on the treatment outcome of hospitals in Ekiti State to the tune of $0.118(\mathrm{p}=0.014<0.05)$ and $0.311(\mathrm{p}=0.000<0.05)$. R-square reported to be 0.240 indicates that the predictor variables considered accounted for about $24 \%$ change in the outcome variable, while the remaining of the change covered by $76 \%$ is as a result of other variables not addressed by this study. Likewise, the Prob(F-stat) of 0.000 which was less than 0.05 proved the model to be fit. 
Table 2: Regression Analysis

Dependent Variable: Increased

\begin{tabular}{lllll}
\hline Variable & Coefficient & Std Error & t-statistics & Prob. \\
\hline (Constant) & 6.208 & 0.65 & 9.558 & 0 \\
Customer Focus & 0.147 & 0.049 & 2.981 & 0.003 \\
Management Commitment & 0.131 & 0.047 & 2.786 & 0.006 \\
Employee Involvement & 0.143 & 0.054 & 2.664 & 0.008 \\
Supplier partnership & 0.174 & 0.049 & 3.568 & 0.000 \\
Training & 0.146 & 0.069 & 2.116 & 0.035 \\
\hline
\end{tabular}

R-Squared $=0.735$

Adjusted R-Squared $=0.540$

F-stat $=68.648$

$\operatorname{Prob}(\mathrm{F}$-stat $)=0.000$

The OLS estimation result presented in Table 7 reveals that customer focus, management commitment, employee involvement, supplier partnership, training exert a positive and significant effect on the increased patronage of hospitals in Ekiti State to the tune of $0.147(\mathrm{p}=0.003<0.05), 0.131(\mathrm{p}=0.06<0.05)$ and $0.143(\mathrm{p}=0.008<0.05), 0.174(\mathrm{p}=0.000<0.05)$ and $0.146(\mathrm{p}=0.035<0.05)$ respectively. $\mathrm{R}$-square reported to be 0.540 indicates that the predictor variables considered accounted for about $54 \%$ change in the outcome variable, while the remaining of the change covered by $46 \%$ is as a result of other variables not addressed by this study. Likewise, the Prob (F-stat) of 0.000 which was less than 0.05 proved the model to be fit.

\subsection{Discussion of Findings}

An attempt has been made to examine the effect of TQM on the non-financial performance of hospitals in Ekiti State. Through the analysis carried out, it was discovered that customer focus, employee involvement and supplier partnership exert a positive but insignificant effect on the treatment outcome of hospitals in Ekiti State. This implies that, in hospitals in Ekiti State, a 1\% increase in customer focus, employee involvement, and supplier partnership would improve, though insignificantly, the treatment outcome by $2.2 \%, 1.3 \%$, and $0.04 \%$ respectively. This confirms that total quality management concerning customer focus, employee involvement, and supplier partnership has not been well-grounded in hospitals in Ekiti State. Also, the result shows that management commitment and training have positive and significant effect on the treatment outcome of hospitals in Ekiti State. This shows that management commitment and training can stimulate a significant increase in the treatment outcome of hospitals in Ekiti State by $11.8 \%$ and $31.1 \%$. It is inferred that management commitment and the amount expended on the training of staff are instrumental to positive treatment outcome of hospitals in Ekiti State. This discovery was in tandem with the findings of Brian et al. (2016) and Rula (2017), that quality management improve treatment outcomes and promote patronage behavior of customers.

It was equally discovered that customer focus, management commitment, employee involvement, supplier partnership, and training exert a positive and significant effect on the increased patronage of hospitals in Ekiti State. This indicates that when it comes to increased patronage, all the mechanisms of TQM are instrumental. Every organization, public or private, always yearn for more customers. On this basis, the findings of this study show that all the mechanisms of TQM are responsible to achieve the desired level of patronage. The study largely corroborate the findings of Brian et al. (2016), Enu (2010), Diamonds (2015), May (2016), Beatrice, Patrick and Bulitia (2016) and El- Moneim and Atef (2015), that total quality management is instrumental to improve the performance level of organizations.

\subsection{Conclusion and Recommendations}

An attempt has been made to examine the effect of TQM on the non-financial performance of Public Tertiary Health Institutions in Ekiti State. Concerning the findings of this study, it was established that customer focus, employee involvement, and supplier partnership exert a positive but insignificant effect on the treatment outcome of hospitals in Ekiti State and that management commitment and training have a positive and significant effect on the treatment outcome of hospitals in Ekiti State. It was equally revealed that customer focus, management commitment, employee involvement, supplier partnership, and training exert a positive and significant effect on the increased patronage of hospitals in Ekiti State. Thus, it was recommended that the management should initiate total quality management initiatives that network the entire organization regularly to attain and sustain high-quality standards and meet customer satisfaction. Right conditions must be created. Being a new management style, staff should be encouraged and motivated to be part of the system and every staff must be part of the system and they must be carried along from the beginning. Hospitals must develop formal reward and recognition systems to encourage employee involvement, and support teamwork, and that the support of top management is a must for TQM to achieve its objectives, especially when the employers pay much attention to motivation. 


\section{REFERENCES}

Abdul-Azeez, I., \& Olateju, O. I. (2015). Effects of Total Quality Management Practices on Customer Satisfaction in Nigeria Airline. LASU Journal of Management Sciences, 2(2).

Ali, K.A.M. and Alolayyan, M. N. (2013). The impact of total quality management (TQM) on the hospital's performance: an empirical research. Int. J. Services and Operations Management, 15(4), 482-506

Ameen, A., George, N. S., Belal, A. M., \& Muhammed, A. (2015). Impact of Total Quality Management on Financial Performance: A Field Study in the Jordan Islamic Bank. International Journal of Business and Social Science, 6(11), 65-82.

Anu P. A. and Satish, K. P. (2016) Investigating the relationship between TQM practices and Firm's performance: A conceptual framework for Indian organizations. Procedia Technology 24, 554-561

Beatrice, D. Patrick, B. O. and Bulitia, G. M. (2016). Analysis of Quality Management Practices and Organizational Performance of Private Healthcare Facilities In Nairobi County, Kenya. International Journal of Novel Research in Marketing Management and Economic, 3(3),115-125.

Biodun, S. (2003). A Proposed Model of Total Quality Management Implementation in the Palestine Context, Total Quality Management and Business Excellence.

Brian, O. O., Chuka, E., Charles, E. O., \& Uzodinma, U. S. (2016). Health Care Quality Management in Nigeria Public Sector; Issues and Prospects. European Journal of Pharmaceutical and Medical Research, 3(4), 7781.

Brook, R. H., McGlynn, E. A., \& Cleary, P. D. (2016). Quality of Health Care. Part 2: Measuring Quality of Care, N Engl J Med, 335(13), 966-970.

Cai, S. (2009). The importance of customer focus for organizational performance: a study of Chinese companies. International Journal of Quality \& Reliability Management, $\quad$ 26(4), 369-379.

Ciama, F. C. (2012). Organizational Theory and Design. U.S.A: South-Western College Publishing.

Davood, G., Hossein, R., Mohammad, R. F., \& Arshad, F. (2013). Total Quality Management and Organizational Performance, American Journal of Industrial Engineering, 1(3), 46-50.

Deming, W. E. (1982), Quality, productivity and competitive position, Massachusetts Institute of Technology, Cambridge.

Diamond, I. M. (2015). Total Quality Management Practices and Operational Performance of Private Hospitals in Nairobi County, (Published Thesis), 1-72.

El-Moneim, A. E., \& Atef, T. A. (2015). The Impact of Applying Total Quality Management Principles on the Overall Hospital Effectiveness: An Empirical Study on the HCAC Accredited Governmental Hospitals in Jordan. European Scientific Journal, 11(10), 63-76.

Enu, C. O. (2010). The Impact of Total Quality Management on Motivation and Performances: A Case Study of Nigeria Custom service. Published Thesis, Ahmadu Bello University Zaria.

Esin, S., \& Hilal, O. (2014). The Effects of Total Quality Management Practices on Performance and the Reasons for and the Barriers to Total Quality management Practices in Turkey. Advances in Decision Science, 1(1), $1-17$

Heizer, J \& Render, B. (2014). Pearson Operations Management, Prentice-Hall, New Jersey.

Ittner, C. D. \& Larcker, D. F. (2005) Total Quality Management and the Choice of Information and Reward Systems. Journal of Accounting Research, 33, 1-34.

Jamali, G., Ebrahim, M., \& Abbazadeh, A. M. (2010). Total Quality Management Implementation: An Investigation of Critical Success Factors. International Conference on Education and Management Technology, 6(3), 147-56.

James, U. M. (2015). Our Total Quality Management Principles Supporting Organizational Performance in Nigeria? Evidence from the Nigeria banking Industry.Special Conference Edition, 1(1), 137-150.

Juran, J. (2006). Quality Improvement. New York: Oxford University Press.

Koenia, P., Erni, T. S., Hilmiana, \& Waode, Z. (2016). Quality Management System and Performance of Organizations. International Journal of Economics, Commerce, and Management, 4(11), 598-611

Li, L.X. and Collier, D.A. (2000) 'The role of technology and quality on hospital financial performance', International Journal of Service Industry Management, 11(3), 202-224

Martin, V., \& Ruiz-Olalla, M. C. (2011). Non-Financial Performance Measure in Quality Environment: Their Contribution to Business performance. Esic Market, 139(1), 169-193.

Mbugua, M. G. (2014). Total Quality Management Critical Success Factors and None-Financial Performance of Deposit Taking Saccos in Nairobi, Kenya, Published Thesis, University of Nairobi, Kenya.

Moballeghi, M., \& Moghaddam, G. G. (2011). Linking Total Quality Management and Financial Performance. 3rd International Conference on Information and Financial Engineering, 12, 417-422.

Mohamed, D. I. (2015). Total Quality Management Practices and Operational Performance of Private Hospital in Nairobi County, (Unpublished Thesis), University of Nairobi.

Mustafa, D., Nizamettin, B. Selim, Z. \& Mehves, T. (2005). Critical Factors of Total Quality Management and Its 
Effect on Performance in Health Care Industry: A Turkish Experience, Problems and Perspectives in Management, 3(4), 220-235.

Nganga, S. I. (2010). Financing Higher Education and the Quality of Education in Tertiary Institutions in Kenya. A Journal of the Kim School of Management, 1(1), 49-57.

Norah, D. A., Sbah, S. A., \&Azrilah, A. A. (2015). The Impact of Total Quality Management on Organizational Performance, European Journal of Business and Management, 7(36), 119-127.

Nwadukwe, U., \& Court, O. T. (2013). Effect of Total Quality Management on Industrial Performance in Nigeria: An Empirical Investigation, European Journal of Business and Management, 5(21), 71-79.

Omogbiya, O. S., \& Addah, G. O. (2016). Effect of Total Quality Management on the Performance of Brewery Industry in Nigeria: An Empirical Study of Selected Breweries in Lagos State, Journal of Social Development, $5(2), 114-121$.

Onwuare, Q. (2012). Determinants of Quality Management Practices. Logistic Information Management, 16(2), $156-171$

Pheny, L. S., \& Teo, A. J. (2003). Implementing Total Quality Management Practices in Constructing Through ISO 9001:2000, Architectural Science Review, 46(2).

Pambrenia, Y., Khatibia, A., Azama, S. M. F., and Tham, J. (2019). The influence of total quality management toward organization performance. Management Science Letters. 9, 1397-1406 doi: 10.5267/j.msl.2019.5.011

Rula, A. A. (2017). The Impact of Total Quality Management on Organizational Performance Case of Jordan Oil Petroleum Company, International Journal of Business and Social Science, 8(1), 192-202.

Sayyard, N. (2017). The Relationship between Total Quality Management Practices and Their Effects on Firms performance in Palestine. Business and Entrepreneurship Journal, 6(2), 35-51.

Sepucha, K., \& Mulley Jr, A. G. (2009). A Perspective on the Patient's Role in Treatment Decisions, Med Care Res Rev, 66, 53S-74S.

Shankar, R. (2012). Industrial Engineering and Management. New Delhi: Galgola Publication Limited.

Simon, S. R., R. Kaushal, P.D. Cleary, C.A. Jenter, L.A. Volk, E.J. Orav, E. Burdick, E.G. Poon, D.W. Bates. (2006). How and Why Are Physicians Using Electronic Health Records? A Statewide Survey, Arch Int. Med.

Wilson, K. C. (2017). Effect of Total Quality Management Practices on organizational Performance in Kenya (Published Thesis), University of Kenya.

Zakuan, N., Muniandy, S., Saman, N. Z., \&Adrif, M. S. (2012). Critical Success Factors of Total Quality Management Implementation in Higher Education Institution: A Review, International Journal of Academic Research in Business and Social Sciences. 2(12). 